\title{
Pulmonary function in bronchial carcinoma
}

\author{
J. S. LEGGE and K. N. V. PALMER \\ Department of Medicine, University of Aberdeen
}

\begin{abstract}
Legge, J. S., and Palmer, K. N. V. (1973). Thorax, 28, 588-591. Pulmonary function in bronchial carcinoma. Pulmonary function was measured preoperatively in 330 patients with bronchial carcinoma. Obstructive bronchitis was present in $62 \%$. Of 225 patients considered fit for thoracotomy and lung resection, 13 developed postoperative ventilatory failure and six died of this. Those who developed ventilatory failure had more marked airway obstruction, lung hyperinflation, and higher arterial carbon dioxide tensions, and also increased respiratory frequencies and physiological dead space/tidal volume ratios on exercise.
\end{abstract}

Bronchial carcinoma is the commonest malignant neoplasm in males. While the overall five-year survival rate is only 3 to $10 \%$, of the 20 to $25 \%$ suitable for surgery, a quarter to a third survive five years (Crofton and Douglas, 1969). Surgical resection, therefore, offers the best prospect of cure, but there is an appreciable postoperative morbidity and mortality from respiratory insufficiency.

\section{PATIENTS AND METHODS}

Three hundred and thirty unselected patients with histologically proven bronchial carcinoma were studied. There were 280 men, mean age 63.2 years (37-80), mean height 1.71 metres (1.54-1.93), and mean weight $66.9 \mathrm{~kg}(42-102)$, and 50 women, mean age 56.6 years $(28-81)$, mean height 1.50 metres $(1.22-$ $1 \cdot 73)$, and mean weight $55.9 \mathrm{~kg}(42-80)$. The forced expiratory spirogram, lung volumes, transfer factor, and arterial blood gas tensions were measured in all the patients, and the cardiorespiratory response to exercise in 65 patients.

From the best of three forced expiratory spirograms (FES) the forced vital capacity (FVC), forced expiratory volume in one second $\left(F E V_{1}\right)$, and the $F E V_{1}$ as a percentage of the FVC $\left(\mathrm{FEV}_{1} \%\right)$ were calculated in litres at ambient temperature pressure saturated with water vapour (ATPS).

To determine the lung volumes, the functional residual capacity (FRC) was measured in duplicate by the closed-circuit multiple breath helium dilution method, and after measuring the inspiratory capacity and expiratory reserve volume, the total lung capacity (TLC), residual volume (RV), and RV/TLC\% were calculated in litres (ATPS).

Single breath carbon monoxide transfer factor (TF) $(\mathrm{ml} / \mathrm{mmHg} / \mathrm{min})$ was measured in duplicate by the method of Ogilvie, Forster, Blakemore, and Morton (1957).
Arterial blood samples were obtained with the $\stackrel{\mathbb{\Phi}}{\mathscr{T}}$ patient breathing air and the arterial oxygen tension $\vec{\omega}$ $\left(\mathrm{PaO}_{2}\right)(\mathrm{mmHg})$ and carbon dioxide $\left(\mathrm{PaCO}_{2}\right)(\mathrm{mmHg}) \omega$ were measured in duplicate using electrodes by Radiometer, Copenhagen.

The effect of exercise was measured on an electrically braked bicycle ergometer at levels between 150 응 and 600 kilopondmetres per minute $(\mathrm{kpm} / \mathrm{min})$ according to the patient's general fitness. After a warm-up $\stackrel{\square}{\Phi}$ period, when the patient was in a steady state, minute ventilation $\left(V_{E}\right)$, mixed expired carbon dioxide content $\left(\mathrm{F}_{\mathrm{ECO}}\right)$, end-tidal carbon dioxide content $\left(\mathrm{F}_{\mathrm{ETCO}}\right)$, and heart rate were measured. From the $\mathrm{F}_{\mathrm{ECO}}$ and $\mathrm{F}_{\mathrm{ETCO}}$, , the physiological dead space/tidal volume ratio per cent (VD/VT\%) was calculated (Jones, 1967).

The mean values for FEV ${ }_{1}$ and FVC, lung volumes, and TF are expressed as a per cent of the predicted $\stackrel{2}{x}$ normal values from tables (Cotes, 1968) to allow for 0 variations in age, sex, and height.

\section{RESULTS}

The abnormalities in pulmonary function found are shown in Table I. There was significant airway을 obstruction $\left(\mathrm{FEV}_{1} \%<70\right)$ and lung hyperinflation

T A B L E I

PULMONARY FUNCTION IN 330 PATIENTS WITH BRONCHIAL CARCINOMA

\begin{tabular}{|c|c|c|c|}
\hline & & $\begin{array}{l}\text { No. of } \\
\text { Patients }\end{array}$ & $\begin{array}{l}\text { Per cent } \\
\text { of Total }\end{array}$ \\
\hline 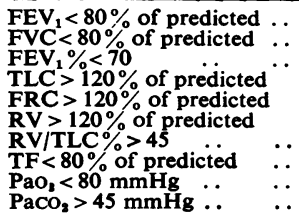 & $\begin{array}{l}. \\
\because \\
\because \\
\because \\
\because \\
\because \\
\because \\
\because\end{array}$ & $\begin{array}{r}221 \\
129 \\
205 \\
54 \\
177 \\
221 \\
205 \\
234 \\
218 \\
33\end{array}$ & $\begin{array}{l}64 \\
39 \\
62 \\
16 \\
54 \\
67 \\
62 \\
71 \\
66 \\
10\end{array}$ \\
\hline
\end{tabular}


(RV\% predicted $>120$ ) in $67 \%$ of the patients. TF was less than $80 \%$ of predicted normal in $71 \%$, $66 \%$ were hypoxaemic, and $10 \%$ hypercapnic. These abnormalities are those characteristically found in chronic obstructive bronchitis (Palmer and Diament, 1970) and were not unexpected since $95 \%$ of the patients were cigarette smokers.

Pulmonary function in smokers and nonsmokers is shown in Table II. Airway obstruction and lung hyperinflation were significantly worse in those who smoked, whereas reduction in TF and $\mathrm{PaO}_{2}$ was no more marked in the smokers than in non-smokers.

\section{TA B LE I I}

MEAN PER CENT PREDICTED PULMONARY FUNCTION IN SMOKERS AND NON-SMOKERS

\begin{tabular}{|c|c|c|c|c|c|}
\hline & & & $\frac{15}{\text { Non-smokers }}$ & $\begin{array}{c}303 \\
\text { Smokers }\end{array}$ & $\underset{\text { Value }}{\mathbf{P}}$ \\
\hline $\begin{array}{l}\text { FEV }_{1} \\
\text { FVC } \\
\text { FEV } \\
\text { TLC } \% \\
\text { FRC } \\
\text { RV } \\
\text { RV/TLC } \\
\text { TF } \\
\mathrm{PaO}_{2} \\
\mathrm{PaCO}_{2}\end{array}$ & $\begin{array}{l}\ldots \\
\ddot{0} \\
\ddot{0} \\
\ddot{\%} \\
\ddot{0} \\
\ddot{0}\end{array}$ & 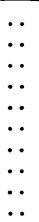 & $\begin{array}{r}79 \cdot 6 \\
84 \cdot 9 \\
75 \cdot 7 \\
91 \cdot 7 \\
111 \cdot 3 \\
106 \cdot 2 \\
42 \cdot 9 \\
64 \cdot 3 \\
73 \cdot 4 \\
38 \cdot 4\end{array}$ & $\begin{array}{r}71 \cdot 9 \\
85 \cdot 3 \\
65 \cdot 1 \\
100 \cdot 0 \\
127 \cdot 7 \\
132 \cdot 0 \\
46 \cdot 5 \\
68 \cdot 2 \\
74 \cdot 6 \\
39 \cdot 8\end{array}$ & $\begin{array}{l}\text { NS } \\
\text { NS } \\
<0.001 \\
\text { NS } \\
<0.01 \\
<0.01 \\
\text { NS } \\
\text { NS } \\
\text { NS } \\
\text { NS }\end{array}$ \\
\hline
\end{tabular}

Exercise testing at two work loads (Table III) also showed abnormalities commonly seen in obstructive bronchitis (Jones, 1966), i.e., high respiratory frequency and increased $\mathrm{VD} / \mathrm{VT}$ ratios, but the minute ventilation and heart rates were within the normal range for subjects at these work loads (Astrand, 1960).

\section{T A B L E II I}

PREOPERATIVE EXERCISE TESTS IN 65 PATIENTS WITH BRONCHIAL CARCINOMA

\begin{tabular}{|c|c|c|c|}
\hline & & \multicolumn{2}{|c|}{ Exercise Load } \\
\hline & & $\begin{array}{c}150-200 \\
\mathrm{kpm} / \mathrm{min}\end{array}$ & $\begin{array}{c}300-400 \\
\mathrm{kpm} / \mathrm{min}\end{array}$ \\
\hline \multicolumn{2}{|c|}{$\begin{array}{l}\text { Mean minute ventilation (predicted } \\
\text { normal) } \\
\text { Mean respiratory rate } \\
\text { Mean heart rate (predicted normai) }\end{array}$} & $\begin{array}{l}19 \cdot 8 \\
(18-22) \\
21 \cdot 5 \\
106 \cdot 2\end{array}$ & $\begin{array}{l}24 \cdot 2 \\
(20-30) \\
23 \cdot 4 \\
119 \cdot 9\end{array}$ \\
\hline $\begin{array}{l}\text { Mean tidal volume }(\mathrm{P}) \\
\text { Mean dead space (P) } \\
\text { Mean VD/VT } \%\end{array}$ & $\begin{array}{ll}\cdots & \cdots \\
\cdots & \cdots \\
\cdots & \cdots\end{array}$ & $\begin{array}{l}0.94 \\
0.33 \\
35 \cdot 5\end{array}$ & $\begin{array}{l}1.05 \\
0.32 \\
30 \cdot 1\end{array}$ \\
\hline
\end{tabular}

Of the 330 patients, 70 were not considered for thoracotomy because of metastatic spread. Of the remaining 260,35 were not considered fit for thoracotomy; this was a decision made mainly on clinical grounds, although pulmonary function tests were available to the clinician. Pulmonary function tests in these 35 compared with 225 who underwent thoracotomy are shown in Table IV.
Those unfit for thoracotomy had significantly worse airway obstruction and lung hyperinflation and a greater reduction in TF and $\mathrm{PaO}_{2}$.

\section{T A B L E I V}

PULMONARY FUNCTION IN PATIENTS CONSIDERED UNFIT FOR LUNG RESECTION AFTER CLINICAL ASSESSMENT

\begin{tabular}{|c|c|c|c|c|c|}
\hline & & & $\begin{array}{l}225 \text { Patients } \\
\text { Fit for } \\
\text { Resection }\end{array}$ & $\begin{array}{l}35 \text { Patients } \\
\text { Unfit for } \\
\text { Resection }\end{array}$ & $\mathbf{P}$ \\
\hline $\begin{array}{l}\mathrm{FEV}_{1}{ }^{1} \\
\mathrm{FVC}^{1} \\
\mathrm{FEV}_{1} \% \\
\mathrm{TLC}_{1}^{1} \\
\mathrm{FRC}^{1} \\
\mathrm{RV}^{1} \\
\mathrm{RV} / \mathrm{TLC}^{\circ} \\
\mathrm{TF} \\
\mathrm{PaO}_{2} \\
\mathrm{PaCO}_{2}\end{array}$ & $\begin{array}{l}\cdots \\
\cdots \\
\cdots \\
0 \\
\cdots \\
\cdots\end{array}$ & $\begin{array}{l}\cdots \\
\cdots \\
\cdots \\
\cdots \\
\cdots \\
\cdots \\
\cdots\end{array}$ & $\begin{array}{r}77 \cdot 0 \\
90 \cdot 2 \\
65 \cdot 6 \\
102 \cdot 6 \\
134 \cdot 0 \\
134 \cdot 0 \\
45 \cdot 6 \\
69 \cdot 0 \\
76 \cdot 9 \\
39 \cdot 6\end{array}$ & $\begin{array}{r}43 \cdot 7 \\
64 \cdot 8 \\
50 \cdot 9 \\
94 \cdot 4 \\
126 \cdot 2 \\
144 \cdot 8 \\
55 \cdot 8 \\
39 \cdot 0 \\
68 \cdot 3 \\
40 \cdot 8\end{array}$ & $\begin{array}{l}<0.001 \\
<0.001 \\
<0.001 \\
<0.02 \\
\text { NS } \\
\text { NS } \\
<0.001 \\
<0.001 \\
<0.001 \\
\text { NS }\end{array}$ \\
\hline
\end{tabular}

1 Per cent of predicted normal values

Of the 225 considered fit for thoracotomy, 53 were found to have inoperable tumours at operation, pneumonectomy was performed in 102, lobectomy in 69, and one patient had a segmental resection. Thirteen patients developed postoperative ventilatory failure (hypercapnic/type 2 respiratory failure (Flenley, 1970) )-seven after pneumonectomy, five after lobectomy, and one after thoractomy only. Six patients died of this complication.

\section{T A B L E V}

PREOPERATIVE PULMONARY FUNCTION AND POSTOPERATIVE PULMONARY INSUFFICIENCY

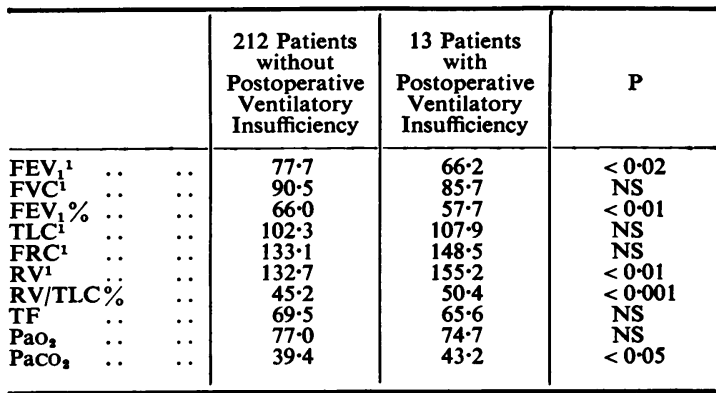

1 Per cent of predicted normal values

Table $\mathrm{V}$ shows that those who developed postoperative ventilatory failure had significantly more airway obstruction and lung hyperinflation and higher mean $\mathrm{PaCO}_{2}$ levels preoperatively than those who did not develop postoperative ventilatory failure. They also had significantly higher mean respiratory frequencies, lower tidal volumes, and higher VD/VT ratios on exercise (Table VI) but the other pulmonary function tests did not help to identify this high risk group. 
T A B L E V I

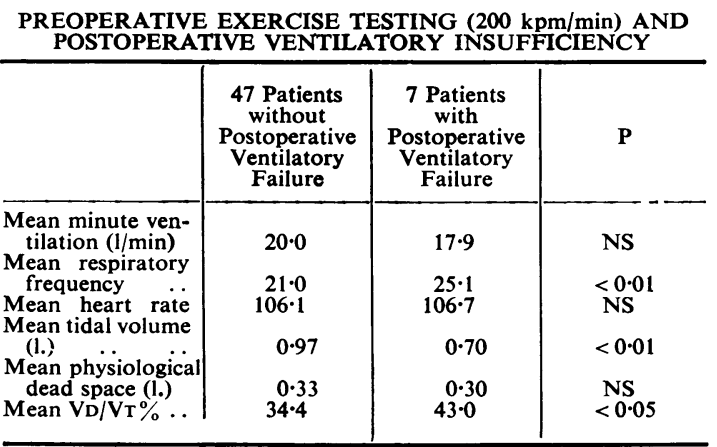

\section{DISCUSSION}

Airway obstruction and lung hyperinflation were present in two-thirds of the patients with bronchial carcinoma and all of these were cigarette smokers. Airway obstruction due to large centrally placed tumours (Simonsson and Malmberg, 1964) was not seen in our patients. Hypercapnia occurred only in patients with severe obstructive lung disease.

The cardiorespiratory response to exercise was that usually found in chronic obstructive bronchitis (Jones, 1966). The minute ventilation, respiratory rate, and tidal volume increased with increasing work loads, whereas the raised $\mathrm{V}_{\mathrm{D}} / \mathrm{V}_{\mathrm{T}} \%$ at rest improved slightly on exercise. The heart rates were within the normal range for suhjects at these work loads.

Much has been written about the value of preoperative pulmonary function measurement in patients undergoing lung resection. Mittman (1961) concluded that the postoperative mortality after lung resection correlated better with the preoperative lung function than with the amount of lung resected, and Filley (1966) said that patients with only moderately reduced pulmonary function are at greatest risk because their danger goes unrecognized without pulmonary function measurement.

There is no general agreement about which pulmonary function tests are of most value in detecting the danger of postoperative respiratory insufficiency. Some have advocated analysis of tests of maximum ventilatory function (Woodruff, Merkel, and Wright, 1953 ; Bergan, 1956 ; Pecora, 1962), while others have been unimpressed by the value of these measurements (Larsen and Cliffton, 1965; Karliner, Coomaraswamy, and Williams, 1968). Mittman (1961) found that where the $\mathrm{RV} / \mathrm{TLC} \%$ was greater than 50 , the postoperative mortality rate was $36 \%$, whereas when this ratio was less than 40 , the mortality rate was only $8 \%$.
Thus the presence of lung hyperinflation, presum- $\frac{\overline{ }}{\overline{0}}$ ably secondary to obstructive lung disease, was of $\frac{\bar{c}}{\frac{1}{5}}$ ominous prognostic significance, and this is in $\stackrel{\varnothing}{\varrho}$ keeping with our own findings.

Bergan (1956) considered the presence of hypo- $\vec{A}$ xaemia a danger sign whereas others have considered hypercapnia to be more important $\vec{\omega}$ (Woodruff et al., 1953 ; Karliner et al., 1968). Cer-疋 tainly we found hypercapnia of greater importance $\vec{x}$ than hypoxaemia, possibly because hypercapniaĩ is related to the presence of severe obstructive $i r$ lung disease whereas hypoxaemia can also be dueci to the tumour causing lung collapse and con- $\infty$ sequent right-to-left shunting of pulmonary blood.음

The patients considered unsuitable for lung $-\overrightarrow{ }$ resection on clinical grounds in this series had $\mathcal{D}_{\mathbb{D}}$ severely abnormal pulmonary function with con- $-\frac{\mathbb{O}}{\mathbb{Q}}$ siderable airway obstruction, lung hyperinflation, $\frac{\mathbb{D}}{3}$ reduced transfer factor, and hypoxaemia. However, in spite of the exclusion of this high risk group, 13 of the 225 patients considered (on clinical $\vec{\bullet}$ examination) to be fit for thoracotomy and lung $\omega$ resection developed postoperative ventilatory failure. Six of them died of this and seven survived with tracheostomy and assisted ventilation.

The mean preoperative pulmonary functiong tests of these 13 patients when compared with the $\frac{\Omega}{\mathbb{Q}}$ 212 who underwent thoracotomy and resection $\overrightarrow{\vec{F}}$ without developing postoperative ventilatory in-응 sufficiency shows that the former had significantly greater airway obstruction, lung hyperinflation and $\mathrm{PaCO}_{2}$ levels. They also had a poorer response to exercise in that the respiratory frequency and $\vec{\sigma}$ the $V_{D} / V_{T}$ ratios were higher at low work loads.

Many factors contribute to postoperative mor $-\dot{x}$ bidity and mortality after lung resection, includ- -3 ing age, presence of cardiac disease, hypertension, cerebral vascular disease, and impaired renal or hepatic function, so that assessment of fitness foro thoracic surgery cannot be based solely on? measurement of pulmonary function. Neverthelesso we suggest that the following tests of pulmonary function are the most valuable in predicting theor risk of postoperative ventilatory failure: $\mathrm{FEV}_{1}, \mathbb{N}$ $\mathrm{FEV}_{1} \%, \mathrm{RV}, \mathrm{RV} / \mathrm{TLC} \%, \mathrm{PaCO}_{2}$, and respiratory rate, $V_{\mathrm{D}} / \mathrm{V}_{\mathrm{T}} \%$ on exercise.

On the cther hand, the FVC, TLC, FRC, TF, $\mathrm{PaCO}_{2}$, and minute ventilation and heart rate one exercise were not found helpful in recognizing this high risk group.

The smoking of cigarettes and the amountos smoked (Palmer, 1954) are closely linked with the development of bronchitis. Cigarette smoking is by far the most important aetiological factor yeto recognized in the development of bronchial car cinoma (Doll and Hill, 1952) and it is clear fromo 
this study that cigarette smoking, in addition to being a factor in the development of the malignant disease, also precludes in a number of patients their chance of cure by radical surgery.

Our thanks are due to Mr. F. J. Sambrook Gowar and Mr. P. L. Brunnen for permission to study their patients, and to Fiona Fiddes and Keith Minty for technical assistance. During this work Dr. Legge held a Medical Research Council Junior Research Fellowship. We gratefully acknowledge the support given by the Medical Research Council.

Requests for reprints should be addressed to $\mathrm{Dr}$ K. N. V. Palmer, University Department of Medicine, Foresterhill, Aberdeen AB9 2ZD.

\section{REFERENCES}

Astrand, I. (1960). Aerobic work capacity in men and women with special reference to age. Acta Physiologica Scandinavica, 49, Suppl. p. 169.

Bergan, F. (1956). Indications and results in lung surgery as revealed by the functional study. Acta Chirurgica Scandinavica, 111, 214.

Cotes, J. E. (1968). Lung Function: Measurement and Application in Medicine, 2nd ed. Blackwell, Oxford.

Crofton, J., and Douglas, A. (1969). Respiratory Diseases. Blackwell, Oxford.

Doll, R., and Hill, A. B. (1952). A study of the aetiology of carcinoma of the lung. British Medical Journal, 2, 1271.

Filley, G. F. (1966). Editorial. Pulmonary function tests: when superfluous, when helpful, when essential? American Review of Respiratory Diseases, 93, 280.

Flenley, D. C. (1970). Respiratory failure. Scottish Medical Journal, 15, 61 .
Jones, N. L. (1966). Pulmonary gas exchange during exercise in patients with chronic airway obstruction. Clinical Science, 31, 39.

- (1967). Exercise testing. British Journal of Diseases of the Chest, 61, 169.

Karliner, J. S., Coomaraswamy, R., and Williams, M. H. (1968). Relationship between preoperative pulmonary function studies and prognosis of patients undergoing pneumonectomy for carcinoma of the lung. Diseases of the Chest, 54, 112.

Larsen, M. C., and Cliffton, E. E. (1965). The prognostic value of preoperative evaluation of patients undergoing thoracic surgery. Diseases of the Chest, 47, 589.

Mittman, C. (1961). Assessment of operative risk in thoracic surgery. American Review of Respiratory Diseases, 84, 197.

Ogilvie, C. M., Forster, R. E., Blakemore, W. S., and Morton, J. W. (1957). A standardized breath-holding technique for the clinical measurement of the diffusing capacity of the lung for carbon monoxide. Journal of Clinical Investigation, 36, 1.

Palmer, K. N. B. (1954). The role of smoking in bronchitis. British Medical Journal, 1, 1473.

- and Diament, M. L. (1970). A comparison of pulmonary function in bronchial asthma and chronic obstructive bronchitis. Thorax, 25, 101.

Pecora, D. V. (1962). Evaluation of cardiopulmonary reserve in candidates for chest surgery. Journal of Thoracic and Cardiovascular Surgery, 44, 60.

Simonsson, B. G., and Malmberg, R. (1964). Differentiation between localized and generalized airway obstruction. Thorax, 19, 416.

Woodruff, W., Merkel, C. G., and Wright, G. W. (1953). Decisions in thoracic surgery as influenced by the knowledge of pulmonary physiology. Journal of Thoracic Surgery, 26, 156. 